\title{
PENGARUH SERANGAN HAMA PENGGEREK BATANG DAN PENYAKIT TUNGRO TERHADAP PRODUKTIVITAS SEMBILAN VARIETAS PADI DI LOKAPAKSA, BALI
}

\author{
Made Suarsana, I Putu Parmila, Putu Sri Wahyuni, I Gusti Made Suarmika \\ Program Studi Agroteknologi, Fakultas Pertanian, Universitas Panji Sakti \\ Jalan Bisma No. 22, Singaraja, Bali, Indonesia 81116 \\ Email korespondensi: made.suarsana02@gmail.com
}

\begin{abstract}
The study was aimed at testing the varieties of rice plants (Oryza sativa L.) On the attack of Plant Disturbing Organisms (OPT), especially on the attack of stem borer pests and tungro disease. The study was conducted from 4 September to 12 December 2019, at the Tangguwisia Pest Forecasting Laboratory (LPHP), in Subak Umadesa, Lokapaka Village, Seririt District, Buleleng Regency. The experiment was arranged in a Randomized Block Design (RCBD). Different rice varieties (9 types) were determined as treatments. Each variety tested was repeated 3 times so that in this test there were 27 treatment units with the type of rice varieties used as follows: PB 64, Mikongga, Sentani, Ciherang. Inpari 30. Tropiko. Cigeulis Inpari 4 and Cibogo. The results of the measurement and analysis showed that: 1. Plant Pests Organisms (OPT) that attack are tungro diseases and stem borer pests; 2. Attack of tungro disease is very low and has no significant difference, so the resistance level of the tested varieties cannot be determined. But the Mikongga variety is the most resistant compared to other varieties: 3 . Stem borers in the varieties tested were generally not significantly different. The degree of varietate resistance to stem borer pests cannot be determined because the attack is still below the economic threshold (<10\%); and 4. The production obtained was significantly different between the varieties tested. The highest production is in the Ciherang variety, which is 11.41 tons $\mathrm{ha}^{-1}$ and the lowest in Cigeulis variety is 9.52 ton $h a^{-1}$.
\end{abstract}

Keywords: stem borer, tungro disease, productivity, rice plants variety

\begin{abstract}
Abstrak: Penelitian bertujuan untuk menguji sembilan varietas tanaman padi (Oryza sativa L.) terhadap serangan hama penggerek batang dan penyakit tungro. Penelitian dilaksanakan tanggal 4 September sampai dengan 12 Desember 2019, di Laboratorium Peramalan Hama Penyakit (LPHP) Tangguwisia, di Subak Umadesa, Desa Lokapaksa, Kecamatan Seririt, Kabupaten Buleleng. Percobaan disusun dalam Rancangan Acak Kelompok (RAK). Varietas padi yang berbeda ( 9 jenis) ditetapkan sebagai perlakuan dan diulang sebanyak 3 kali sehingga pada pengujian ini terdapat 27 unit perlakuan dengan jenis varietas padi yang digunakan yaitu: PB 64, Mikongga, Sentani, Ciherang, Inpari 30, Tropiko, Cigeulis, Inpari 4 dan Cibogo. Parameter yang diamati adalah produktivitas hasil ubinan. Hasil pengamaan dan analisis menunnjukkan bahwa: 1. Organisme Pengganggu Tumbuhan (OPT) yang menyerang: Penyakit tungro dan hama penggerek batang; 2 . Serangan penyakit tungro sangat rendah dan berbeda tidak nyata, sehingga tingkat ketahanan varietas yang diuji tidak dapat ditentukan. 3 . Serangan hama penggerek batang berbeda tidak nyata. Tingkat ketahanan varietas terhadap hama penggerek batang belum bisa ditentukan karena serangan masih dibawah ambang batas ekonomis $(<10 \%)$; dan 4. Produksi antar perlakuan menunjukkan hasilnya yang tidak berbeda nyata. Produktivitas tertinggi terdapat pada varietas Ciherang, yaitu 11,41 ton ha ${ }^{-1}$ dan terendah pada varietas Cigeulis yaitu 9,52 ton ha- ${ }^{-1}$.
\end{abstract}

Kata kunci: penggerek batang, penyakit tungro, produktivitas, varietas padi

\section{PENDAHULUAN}

Di Indonesia yang beriklim tropis, padi ditanam di seluruh daerah dataran rendah sampai dataran tinggi. Umumnya padi diusahakan sebagai padi sawah $(85-90 \%)$ dan sebagian kecil (10-15\%) sebagai padi gogo (Andripa, 2017).

Untuk meningkatkan produksi padi nasional, pemerintah telah melakukan berbagai upaya, termasuk 
mendorong penggunaaan teknologi baru seperti varietas unggul yang berperan dalam meningkatkan produktivitas dan produksi beras nasional (Wahyuni et al., 2018), pengairan yang teratur, teknik budidaya SRI hemat air tapi optimal bagi pertumbuhan (Purba, 2009), pemupukan yang tepat, perbaikan cara bercocok tanam, pengendalian hama dan penyakit, disamping peningkatan penyuluhan, penyediaan kredit, pemberian subsidi terhadap sarana produksi dan perbaikan pemasaran hasil (Taslim et al., 2010). Sehingga, usaha peningkatan produksi harus dilakukan secara sinergis, meliputi pengelolaan pembibitan, kesuburan tanah dan pemanfaatan hara, pengairan, pengendalian hama dan penyakit, gulma serta penggunaan alat mesin pertanian yang kemudian dikenal sebagai pengelolaan tanaman terpadu (PTT) (Abdullah et al., 2008).

Program peningkatan produksi tanaman pangan khususnya padi banyak mendapat rintangan salah satu diantaranya adalah adanya serangan organisme pengganggu tumbuhan (OPT). OPT pada tanaman padi sangat kompleks, sehingga apabila tidak ditangani secara benar akan dapat menimbulkan resiko yang tinggi (Muhsin dan Widiarta, 2019). Sehubungan dengan itu sistem perlindungan memegang peranan penting dalam budidaya tanaman padi. Penanganan OPT dirasakan sangat berat, mengingat semua fase pertumbuhan berpotensi untuk dirusak (Syahri dan Somantri, 2016). Maka dari itu, mekanisme kerja perlindungan tanaman perlu perencanaan yang matang sehingga dapat menutup ruang dan waktu kemunculan OPT baru. Jika hal itu terjadi dengan segera dapat dikendalikan.

Serangan hama dan penyakit seperti penggerek batang, wereng coklat, tikus, penyakit tungro dan blas merupakan OPT utama padi yang ditakuti petani (Sudarma et al., 2016). OPT tersebut dapat muncul kapan dan dimana saja tanpa dapat diduga sebelumnya. Serangan dapat meningkat dengan cepat apabila dalam ekosistim tersedia banyak faktor pendukungnya. Kerusakan tanaman akan bertambah parah ketika dalam satu fase pertumbuhan diserang oleh dua atau lebih jenis OPT yang berbeda, apalagi munculnya serangan di awal penanaman (G. Kumar et al., 2019).

Reaksi OPT terhadap varietas padi dibedakan menjadi 2 jenis yaitu varietas peka/rentan dan varietas tahan (Prabawa et al., 2015). Pada varietas peka, suatu OPT dapat hidup lebih baik dan berkembang dengan cepat jika dibandingkan pada varietas tahan. Ketahanan yang dimiliki varietas padi berbeda-beda, dapat berupa ketahanan fisik, toleran dan antibiosis. Terlepas dari sifat tahan tersebut, dengan terhambatnya perkembangan suatu OPT pada varietas tahan maka jenis varietas tersebut dapat dijadikan sebagai salah satu paket teknologi pengendalian OPT.

Sifat ketahanan yang dimiliki varietas padi tidak stabil, dengan kata lain ketahanan suatu varietas dapat berubah karena beberapa OPT keturunannya memiliki variasi genetik yang tinggi dan dibawah pengaruh tekanan seleksi alam dapat beradaptasi sehingga sifatnya berbeda, jauh lebih ganas dari semula. 
Perubahan sifat suatu OPT akan terjadi setidaknya dalam 5 kali musim tanam, jika dilakukan penanaman varietas padi yang sejenis terus menerus pada hamparan yang luas (Sodiq, 2009). Populasi OPT yang beradaptasi tersebut akan dapat mamatahkan varietas padi yang semula termasuk dalam katagori tahan menjadi mudah terserang (peka). Perkembangan ilmu pengetahuan dan teknologi khususnya dalam bidang pertanian memberi inspirasi bagi petani untuk meningkatkan hasil, namun pada keadaan lain tidak jarang membawa dampak negatif yang berujung dengan kerugian. Merambahnya penanaman varietas baru tanpa memiliki diskripsi yang jelas, sering kali dapat memicu terjadinya serangan hama maupun penyakit. Demikian pula pelaksanaan di lapangan tidak mengikuti petunjuk teknis petugas terkait dan kaidahkaidah pengendalian pada umumnya. Sehubungan dengan itu, maka perlu dilakukan kegiatan pengujian varietas untuk memperoleh/mendapatkan informasi ketahanan varietas sehingga nantinya dapat dijadikan salah satu bahan pertimbangan dalam rangka menyusun teknologi pengendalian OPT utama padi.

\section{BAHAN DAN METODE}

Penelitian dilaksanakan tanggal

4 September sampai dengan 12 Desember 2019. Penelitian di laksanakan di Laboratorium Peramalan Hama Penyakit (LPHP) Tangguwisia. Pengujian tanaman padi dilakukan di Subak Umadesa, Desa Lokapaksa, Kecamatan Seririt, Kabupaten Buleleng.
Pelaksanaan analisis data pada kegiatan pengujian varietas tanaman padi berpedoman pada Rancangan Acak Kelompok (RAK). Varietas padi yang berbeda (9 jenis) ditetapkan sebagai perlakuan. Tiap varietas yang diuji diulang sebanyak 3 kali sehingga pada pengujian ini terdapat 27 unit perlakuan dengan jenis varietas padi yang digunakan sebagai berikut: $\mathrm{A}=\mathrm{PB}$ 64, $\mathrm{B}=$ Ciherang, $\mathrm{C}=$ Cigeulis $\mathrm{D}=$ Mikongga, $\mathrm{E}=$ Inpari $30 \mathrm{~F}=$ Inpari $4 \mathrm{G}=$ Sentani, $\mathrm{H}=$ Tropiko, $\mathrm{J}=$ Cibogo. Parameter pengamatan yanng diamati adalah produktivitas berdasarkan pada produksi hasil ubinan.

\section{HASIL DAN PEMBAHASAN}

Dari hasil pelaksanaan kegiatan tata laksana penelitian sembilan varietas tanaman padi pada musim tanam 2019 dijumpai 2 jenis organisme pengganggu Tumbuhan (OPT) utama yaitu : penyakit tungro dan penggerek batang. OPT utama padi lainnya seperti: hama tikus, blas dan wereng batang coklat tidak dijumpai menyerang tanaman pengujian. Keadaan serangan OPT utama padi pada masing-masing tanaman yang diuji dapat diinformasikan sebagai berikut.

\section{A. Penyakit Tungro}

Provinsi Bali menempati posisi ketiga pada wilayah yang terkena serangan tungro tertinggi pada tahun 2006, dengan luas serangan $1.093 \mathrm{Ha}$ (BBPOPT, 2010). Gejala utama penyakit tungro tampak pada perubahan warna pada daun muda menjadi kuning oranye dimulai dari ujung daun, jumlah anakan berkurang, tanaman kerdil dan pertumbuhannya terhambat. Hal ini 
disebabkan kerusakan floem dan xylem (Gaurav Kumar and Dasgupta, 2020; Valarmathi \& Ladhalakshmi, 2019). Gejala penyakit tersebar mengelompok, hamparan tanaman padi terlihat seperti bergelombang karena adanya perbedaan tinggi tanaman antara tanaman sehat dan yang terinfeksi (Said, 2007). Gejala serangan penyakit tungro pada pengujian varietas tanaman padi di Subak Umadesa, Desa Lokapaksa mulai muncul pada umur 3 minggu setelah tanam (mst) pada semua varietas yang diuji yaitu: PB 64, Ciherang, Cigeulis, Mekongga, Inpari 30, Inpari 4, Sentani, Tropiko, dan Cibogo, dengan intensitas serangan sangat rendah. Memperhatikan saat munculnya gejala serangan penyakit tungro secara umum \pm 14 hari setelah inokulasi, maka dapat diduga bahwa infeksi penyakit tungro terjadi setelah dilakukan penanaman di lapangan, bukan sewaktu dalam fase pesemaian. Varietas padi yang diuji terserang tungro dan menunjukkan peningkatan sejalan dengan bertambahnya umur tanaman. Secara kuantitatif peningkatan serangan terjadi setiap minggu pada semua varietas yang diuji. Puncak serangan penyakit tungro pada semua varietas padi yang diuji terjadi pada umur 9 minggu setelah tanam (mst) hal ini sesuai dengan pernyataan Sutrawati et al. (2019) yang menyatakan gejala serangan tungro akan timbul pada 615 hari setelah terinfeksi.

\section{B. Penggerek Batang}

Selain penyakit tungro, saat pengamatan juga dijumpai serangan hama penggerek batang padi. Kehadiran hama tersebut di lapangan menyebabkan kerusakan pada anakan tanaman padi, yang populer disebut sundep (dead heart) pada fase vegetatif dan beluk (white ear head) pada fase generatif (Baehaki, 2015). Hama ini mulai ada saat tanaman padi berumur 3 mst. Serangan hama penggerek batang pada minggu ketiga hanya menyerang beberapa varietas yang diuji, seperti varietas PB 64, Cigeulis, Inpari 4, Sentani, Tropiko, dan Cibogo. Pada minggu keempat, semua varietas yang diuji terserang hama penggerek batang dengan intensitas serangan ringan. Puncak serangan hama penggerek batang di Subak Umadesa, Desa Lokapaksa, Kecamatan Seririt terjadi pada fase generatif, pada umur $11 \mathrm{mst}$. Hal ini sesuai dengan hasil penelitian Aryantini et al. (2015), yang menyatakan bahwa mulai umur tanaman 7 mst hingga 11 mst akan terjadi peningkatan serangan dan setelah itu akan mulai menurun.

\section{Produktivitas Tanaman Padi}

Produksi tanaman padi dipengaruhi oleh faktor dalam yang sering disebut faktor genetis dan faktor luar (lingkungan). Salah satu faktor luar yang mempengaruhi tinggi rendahnya produksi tanaman adalah serangan organisme pengganggu tumbuhan (OPT). Pada umumnya tingkat kerusakan tanaman oleh OPT berbanding lurus dengan produksi tanaman. Pada tingkat serangan rendah akan terjadi penurunan produksi yang relatif rendah dan sebaliknya pada tingkat serangan yang lebih tinggi menyebabkan penurunan produksi yang semakin tinggi.

Produksi varietas padi berbeda nyata antar varietas yang diuji, yaitu produksi tertinggi 11,41 ton/ha pada 
varietas Ciherang berbeda nyata dengan varietas Cigeulis yang produksinya hanya mencapai 9,52 ton/ha. Produksi tertinggi pada varietas Ciherang berbeda tidak nyata dengan produksi varietas Mikongga, Inpari 30, Inpari 4, Sentani, Tropiko, dan Cibogo. Sedangkan produksi terendah pada varietas Cigeulis Tabel 1. Produksi Hasil Ubinan Tata Laksana Penelitian Sembilan Varietas Tanaman Padi di Subak Umadesa, Desa Lokapakasa, Kecamatan Seririt, Kabupaten Buleleng

\begin{tabular}{|l|l|c|c|c|c|}
\hline \multirow{2}{*}{ No. } & \multirow{2}{*}{ Perlakuan } & \multicolumn{4}{|c|}{ Produksi Ubinan (Kg) } \\
\cline { 3 - 6 } & & I & II & III & Rerata \\
\hline 1 & A (PB 64) & 5,20 & 6,03 & 6,85 & 6,03 \\
\hline 2 & B (Ciherang) & 6,35 & 7,13 & 7,90 & 7,13 \\
\hline 3 & C (Cigeulis) & 6,00 & 5,95 & 5,90 & 5,95 \\
\hline 4 & D (Mikongga) & 6,70 & 6,65 & 6,80 & 6,72 \\
\hline 5 & E (Inpari 30) & 5,85 & 6,36 & 7,10 & 6,44 \\
\hline 6 & F (Inpari 4) & 7,40 & 6,93 & 6,47 & 6,93 \\
\hline 7 & G (Sentani) & 6,32 & 6,20 & 6,00 & 6,17 \\
\hline 8 & H (Tropiko) & 6,57 & 6,79 & 7,00 & 6,79 \\
\hline 9 & J (Cibogo) & 7,30 & 6,95 & 6,50 & 6,92 \\
\hline \multicolumn{2}{|l|}{ BNT 5\% } \\
\hline
\end{tabular}

Keterangan $: \mathrm{tn}=$ uji $\mathrm{F}$ tidak berbeda nyata

Tabel 2. Produktivitas Sembilan Varietas Tanaman Padi Hasil Konversi dari Data Dasar Hasil Ubinan

\begin{tabular}{|c|c|c|c|c|c|}
\hline \multirow{2}{*}{ No. } & \multirow{2}{*}{ Perlakuan } & \multicolumn{4}{|c|}{ Produktivitas (ton ha ${ }^{-1}$ ) } \\
\hline & & I & II & III & Rerata \\
\hline 1 & $\mathrm{~A}(\mathrm{~PB} 64)$ & 8,32 & 9,64 & 10,96 & 9,65 \\
\hline 2 & B (Ciherang) & 10,16 & 11,40 & 12,64 & 11,41 \\
\hline 3 & $\mathrm{C}$ (Cigeulis) & 9,60 & 9,52 & 9,44 & 9,52 \\
\hline 4 & D (Mikongga) & 10,72 & 10,64 & 10,88 & 10,75 \\
\hline 5 & E (Inpari 30) & 9,36 & 10,19 & 11,36 & 10,30 \\
\hline 6 & F (Inpari 4) & 11,84 & 11,09 & 10,35 & 11,09 \\
\hline 7 & G (Sentani) & 10,11 & 9,92 & 9,60 & 9,87 \\
\hline 8 & H (Tropiko) & 10,51 & 10,86 & 11,20 & 10,86 \\
\hline 9 & $\mathrm{~J}$ (Cibogo) & 11,68 & 11,12 & 10,40 & 11,07 \\
\hline \multicolumn{5}{|c|}{ BNT $5 \%$} & tn \\
\hline
\end{tabular}

Keterangan : $\mathrm{tn}=$ uji $\mathrm{F}$ tidak berbeda nyata

\section{SIMPULAN}

Organisme

Pengganggu

Tumbuhan (OPT) yang menyerang pada pengujian varietas tanaman padi berbeda tidak nyata dengan varietas PB 64, Mikongga, Inpari 30, Sentani, dan Tropiko. Perbedaan produksi diantara varietas yang diuji kemungkinan disebabkan oleh perbedaan genetis yang dimiliki masing-masing varietas (tabel 1 dan 2). 
Serangan penyakit tungro di Subak Umadesa, Desa Lokapaksa, Kecamatan Seririt sangat rendah, sehingga tingkat ketahanan varietas yang diuji tidak dapat ditentukan.

Serangan hama penggerek batang pada varietas yang diuji belum menunjukkan tingkat serangan yang tinggi, sehingga tingkat ketahanan varietas terhadap hama penggerek batang belum bisa ditentukan karena serangan masih dibawah ambang batas ekonomis $(<10 \%)$.

Varietas yang menunjukkan produktivitas paling tinggi adalah varietas Ciherang sebesar 11,41ton $\mathrm{ha}^{-1}$ sedangkan produktovitas terendah ditunjukkan oleh varietas Cigeulis dengan produktivitas 9,52 ton ha $^{-1}$, meskipun secara statistik produktivitas antar varietas tidak berbeda nyata.

\section{SARAN}

Pada daerah endemis penyakit tungro dapat dilakukan penanaman varietas Mikongga dan hindari melakukan penanaman varietas Cigeulis.

Perlu dilakukan pengujian yang sama pada lokasi dan musim tanam yang berbeda, sehingga bisa diketahui tingkat ketahanan dari sembilan varietas padi yang diuji pada berbagai lokasi dan musim tanam.

\section{DAFTAR PUSTAKA}

Abdullah, B., Tjokrowidjojo, S., \& Sularjo. (2008). Perkembangan dan Prospek Perakitan Padi Tipe Baru di Indonesia. J. Litbang Pertanian, 27(1), 1-9.

Andripa. (2017). Penentuan Waktu Uji Cepat Vigor Benih dengan Metode Pemunculan Radikula (Radicle Emergence) Pada
Beberapa Varietas Padi (Oryza sativa L.). [Skripsi]. Institut Pertanian Bogor.

Aryantini, L. T., Supartha, I. W., \& Wijaya, I. N. (2015). Kelimpahan Populasi dan Serangan Penggerek Batang Padi pada Tanaman Padi di Kabupaten Tabanan. $J$. Agroekoteknologi Tropika, 4(3), 203-212.

Baehaki, S. E. (2015). Hama penggerek batang padi dan teknologi pengendalian. Iptek Tanaman Pangan, 8(1), 1-14.

BBPOPT. (2010). Meramal OPT utama padi MK 2010. Buletin Peramalan OPT, 8(1).

Kumar, G., Jyothsna, M., Valarmathi, P., Roy, S., Banerjee, A., Tarafdar, J., Senapati, B. K., Robin, S., Manonmani, S., Rabindran, R., \& Dasgupta, I. (2019). Assessment of resistance to rice tungro disease in popular rice varieties in India by introgression of a transgene against Rice tungro bacilliform virus. Archives of Virology. https://doi.org/10.1007/s00705019-04159-3

Kumar, Gaurav, \& Dasgupta, I. (2020). Comprehensive molecular insights into the stress response dynamics of rice (Oryza sativa L.) during rice tungro disease by RNA-seqbased comparative whole transcriptome analysis. Journal of Biosciences, 45(1), 27. https://doi.org/10.1007/s12038020-9996-X

Muhsin, M. ., \& Widiarta, I. N. (2010). Patosistem, Strategi, dan Komponen Teknologi Pengendalian Tungro pada 
Tanaman Padi. Iptek Tanaman Pangan, 4(2), 202-221.

Prabawa, P. S., Yulianah, I., \& Basuki, N. (2015). Uji Ketahanan 10 Genotip Padi Merah (Oryza sativa L.) Terhadap Penyakit Blas Daun (Pyricularia oryzae Cav.) Ras 173. J. Produksi Tanaman. J. Produksi Tanaman, 3(6), 496502.

Purba, J. H. (2009). Penghematan Air dan Peningkatan Produksi Melalui Budidaya Padi Metode SRI (System of Rice Intensification). Widyatech, Jurnal Sains Dan Teknologi, 9(2), 28-46.

Said, M. Y. (2007). Petunjuk Teknis Pengendalian Terpadu Penyakit Tungro. Badan Penelitian dan Pengembangan Penelitian.

Sodiq, M. . (2009). Ketahanan Tanaman Terhadap Hama. UPN Press.

Sudarma, I. M., Sritamin, N. M., \& Bagus, I. G. N. (2016). Pengendalian Hama dan Penyakit Tanaman Padi di Desa Pesaban, Kecamatan Rendang, Karangasem. J. Udayana Mengabdi, 15(3), 106-112.

Sutrawati, M., Sariasih, Y., Priyatiningsih, \& Ladja, F. T. (2019). Deteksi Virus Tungro Pada Padi di Bengkulu. JIPI, 21(2), 99-102.

Syahri, \& Somantri, R. U. (2016). Penggunaan Varietas Unggul Tahan Hama dan Penyakit Mendukung Peningkatan Produksi Padi Nasional. $J$. Litbang Pert., 35(1), 25-36.

Taslim, H., Partohardono, S., \& Djunainah. (2010). Bercocok Tanam Padi Sawah. Padi Buku 2 (pp. 481-505). Pusat Penelitian dan Pengembangan Tanaman Pangan.

Valarmathi, P., \& Ladhalakshmi, D. (2019). Microtomy Studies of Rice Tungro Disease Infected Leaves. International Journal of Current Microbiology and Applied Sciences. https://doi.org/10.20546/ijcmas. 2019.809.202

Wahyuni, P. S., Srilaba, N., \& Rumtily, E. A. (2018). Pengaruh Varietas dan Kepadatan Tanam Terhadap Pertumbuhan dan Hasil Padi (Oryza sativa L.) pada Lahan Sawah di Anturan. Agro Bali: Agricultural Journal, 1(1), $1-10$. 